\title{
Critical Parameters of Metal Laser Sintering with its Impact on Geometrical Accuracy of a Component
}

Ivana Zetková, Miroslav Zetek, Milan Daňa, Jan Kutlwašer

Faculty of Mechanical Engineering, Západočeská univerzita v Plzni. Univerzitní 8, 30614 Plzeň. Czech Republic. Email: zetkova@rti.zcu.cz, mzetek@rti.zcu.cz, danam@rti.zcu.cz

3D printing of metallic powders is a relatively new but increasingly used technology in a wide range of sectors. Design engineers are responding flexibly to new opportunities for production and components for 3D printing and are designing with respect to the advantages and limitations of this technology. Through the additive method of production, we can produce very specific components with complex shapes, both internal and external, which cannot be produced by conventional methods, thereby opening up new possibilities both in functional components and in their design.

This paper deals with the influence of critical parameters of metal laser sintering of metallic powders, particularly tool steel, on the geometrical accuracy of a component. Based on selected critical parameters, a component was designed that was printed on different devices and subsequently evaluated in terms of accuracy, surface quality and material properties.

Keywords: Metal laser sintering; critical parameters; geometrical accuracy, DLMS, tool steel

\section{Acknowledgement}

The present contribution has been prepared under project LO1502 'Development of the Regional Technological Institute' under the auspices of the National Sustainability Programme I of the Ministry of Education of the Czech Republic aimed to support research, experimental development and innovation.

\section{References}

[1] A.K. MISHRA, S. THIRUMAVALAN (2014). A Study of Part Orientation in Rapid Prototyping. Middle-East Journal of Scientific Research 20 (9): 1197-1201. 2014. ISSN 1990-9233

[2] SENTHILKUMARAN. Influence of building strategies on the accuracy of parts in selective laser sintering

[3] Rapid prototyping and manufacturing technology [online]. 2014 [cit. 2014-11-18]. http://ieeexplore.ieee.org/xpl/articleDetails.jsp?arnumber=6075759

[4] TURKER, M. (2008). Effect of production parameters on the properties of IN 718 superalloy by three-dimensional printing. 2008.

[5] CALIGNANO, F. (2014). Design optimization of supports for overhanging structures in aluminum and titanium alloys by selective laser melting. 2014.

[6] YAN, Ch. (2014). Advanced lightweight 316L stainless steel cellular lattice structures fabricated via selective laser melting. 2014.

[7] WANG, D. (2013). Study on the designing rules and processability of porous structure based on selective laser melting SLM. 2013.

[8] GU, D., SHEN, Y. (2008). Balling phenomena in direct laser sintering of stainless steel powder: Metallurgical mechanisms and kontrol methods. 2008.

[9] SONG, B. (2014). Vacuum heat treatment of iron parts produced by selective laser melting: Microstructure, residual stress and tensile behavior. 2014.

[10] LU, K., REYNOLDS, W. T. (2008). 3DP process for fine mesh structure printing. Powder Technology. 2008 , vol. 187, issue 1, s. 11-18. DOI: 10.1016/j.powtec.2007.12.017.

[11] KUČEROVÁ, L. ZETKOVÁ, I. (2016). Metallography of 3D Printed 1.2709 Tool Steel. In Manufacturing Technology. February 2016, Vol. 16, No.1. s. 140 -144. ISSN 1213-2489

[12] FOUSOVÁ, M. VOJTĚCH, D. KUBÁSEK, J. DVORSKÝ, D. MACHOVÁ, M. (2015). 3D Printing as an Alternative to Casting, Forging and Machining Technologies. In Manufacturing Technology. November 2015 , Vol. 15,No.5. s. 809-814. ISSN 1213-2489

[13] KROTKÝ, J., HONZÍKOVÁ, J., MOC, P. (2016). Deformation of Print PLA Material Depending on the Temperature of Reheating Printing Pad, Published by Manufacturing Technology, ISSN 1213-2489, Paper number: M201628 